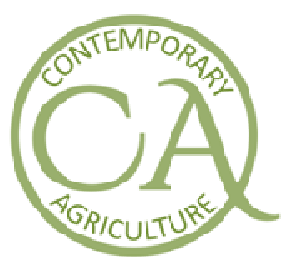

\author{
$S$ sciendo \\ Contemporary Agriculture \\ Serbian Journal of Agricultural Sciences \\ Faculty of Agriculture, University of Novi Sad, Serbia \\ www.contagri.info
}

Original scientific paper

UDC: $599.731 .1: 591.436$

DOI: $10.2478 /$ contagri-2021-0003

\title{
THE OCCURRENCE OF HEAVY METALS (CADMIUM AND LEAD) IN THE LIVER OF HOGS IN THE REGION OF VOJVODINA
}

\author{
MIROSLAVA POLOVINSKI HORVATOVIĆ", IVAN RADOVIĆ, IGOR JAJIĆ, \\ SA ̌́A KRSTOVIĆ, MILE MIRKOV \\ Faculty of Agriculture, University of Novi Sad, Department of Animal Science, Trg Dositeja Obradovića 8, \\ 21000 Novi Sad Serbia \\ *Corresponding author: miroslavapolovinski@yahoo.com
}

\begin{abstract}
SUMMARY
The purpose of this research is to investigate the occurrence of two heavy metals (namely cadmium (Cd) and lead $(\mathrm{Pb})$ ) in the liver of hogs bred in different locations in Vojvodina. A total of 30 liver samples were collected from ten pig farms in Vojvodina for experimental purposes in the period from December 2017 to January 2018. The samples collected were analysed for the presence of lead and cadmium. The average concentration of lead in all the samples was $0.39 \mathrm{mg} / \mathrm{kg}$ wet weight, whereas the samples from only one farm of the ten considered were found to contain a slightly higher average lead concentration than permitted by the Serbian standard. A lead concentration of $0.86 \mathrm{mg} / \mathrm{kg}$ wet weight was detected in one liver sample from this farm. The maximum permitted lead concentration was exceeded in the liver samples obtained from three farms. However, all the liver samples analysed were found to contain the permitted levels of cadmium, with an average cadmium concentration of $0.12 \mathrm{mg} / \mathrm{kg}$ wet weight and a maximum cadmium concentration of $0.48 \mathrm{mg} / \mathrm{kg}$ wet weight. The occurrence of heavy metals and their origin in the pig's offals should be examined in greater detail in future research, especially because pig's offals are used in the meat processing industry.
\end{abstract}

Key words: cadmium, lead, liver, hogs, Vojvodina

\section{INTRODUCTION}

The pork production in Serbia claims the largest share of the Serbian meat production with a volume of 307,000 $\mathrm{t}$ in 2017, compared to a poultry meat production of 95,000 $\mathrm{t}$ and a beef production of 71,000 $\mathrm{t}$ recorded in the same year (the Statistical Yearbook of the Republic of Serbia, 2018). Pork products are one of the most frequently used meat products in Serbia. The quality of meat and meat products is of great importance to end consumers. Heavy metals associated with the anthropogenic effect and the intensive industry can contaminate meat and meat products. Owing to the nature of animal metabolism, edible offals (namely the liver and kidneys) are at the greatest risk of being compromised by heavy metals.

From a food safety perspective, some of the most important heavy metals are cadmium, lead, mercury, copper and arsenic. The Serbian legislation on heavy metals in meat and offals (RS Pravilnik, 2011) is in accordance with the EU legislation (European Commission, 2008). The maximum permitted level of lead and cadmium in offals is $0.5 \mathrm{mg} / \mathrm{kg}$ of wet weight, whereas the cadmium limit in the kidneys has been set at $1 \mathrm{mg} / \mathrm{kg}$ ). Apart from being a food safety issue, heavy metals can adversely affect livestock production by reducing the basic production parameters (Reddy et al., 2017). The quality of pork meat and edible offals is of significant importance to end consumers. Heavy metals can accumulate in meat and, more often, offals such as the liver and/or kidney, thus entering the human food chain and posing a food safety issue.

The source of heavy metals in pig production can be the soil in the proximity of industrial area, the intensive agricultural production or the premix included in animal feed (Reddy et al., 2017; Spahić Poznanović et al., 2018). 
Cadmium (Cd) is a toxic metal which can be found in the environment as the result of human activity, pollution, or some natural activity (Hutton, 1983). Cadmium does not have any biological function in the organism. Although absent at birth, it is accumulated over time mostly in the kidneys and liver of animals, featuring a very long half-life of 10 to 30 years (Andrée et al., 2010). It is classified in the first group of human carcinogens by the International Agency for Research of Cancer (1 group) (IARC, 1993).

Lead $(\mathrm{Pb})$ is also considered toxic for animals and belongs to the second group (IARC, 1993) of the IARC classification. It mostly accumulates in the bones of the exposed animals (95\%) and, to a lesser extent, in their liver and kidneys.

Food is the main source of contamination with toxic metals such as lead, cadmium and mercury in the nonsmoking human population (EFSA, 2009; EFSA, 2010).

The purpose of this research is to investigate the occurrence of two heavy metals (namely cadmium $(\mathrm{Cd})$ and lead $(\mathrm{Pb})$ in the liver of hogs bred in 10 different locations in Vojvodina.

\section{MATERIAL AND METHODS}

\section{Sampling}

Liver samples were taken from random hogs on the slaughter line of three different slaughterhouses in the period from December 2017 to January 2018. The hogs were approximately six months old, weighing 100-110 kg and originating from ten different commercial pig farms in Vojvodina. The hogs' diet was based on the locally produced corn and soybean meals and was formulated to meet the animals' nutritional needs. The fattening of the hogs was divided in three phases: the starting, growing and finishing periods. Upon homogenization, all the samples were frozen at $-20{ }^{\circ} \mathrm{C}$ until further analysis.

\section{Analytical methods}

Lead and cadmium concentrations were determined after the wet sample digestion in concentrated nitric and hydrochloric acid $(3: 1, v / v)$ using a Reacti-ThermTM Heating/Stirring module Thermo Scientific (Rockford, USA). The analysis was performed using a Perkin-Elmer PinAAcle 900T THGA/FL atomic absorption spectrometer, a longitudinal Zeeman-effect background correction system, equipped with a transversely heated graphite atomizer (THGA) and an AS900 auto sampler. Hollow cathode lamps (HCL) were used for lead and cadmium detection. The analysis was carried out according to the method described by Beuković et al. (2015).

\section{RESULTS AND DISCUSSION}

The levels of lead $(\mathrm{Pb})$ and cadmium $(\mathrm{Cd})$ determined in the hog liver samples analysed are presented in Tables 1 and 2, respectively. The two heavy metals considered were found to be above the limit of detection in all the samples analysed. Overall, the average concentration of cadmium was lower than the average concentration of lead. The concentration of lead exceeded the permitted level in the liver samples from several farms, especially Farm III.

Table 1. Occurrence of lead in the liver of hogs from $10 \mathrm{pig}$ farms in Vojvodina ( $\mathrm{mg} / \mathrm{kg}$ wet weight)

\begin{tabular}{lccccccccccc}
\hline Farm & I & II & III & IV & V & VI & VII & VIII & IX & X & Total \\
\hline No & 4 & 2 & 4 & 4 & 2 & 4 & 4 & 2 & 2 & 2 & 30 \\
Average & 0.44 & 0.36 & 0.58 & 0.39 & 0.31 & 0.40 & 0.38 & 0.41 & 0.21 & 0.23 & 0.39 \\
Maximum & 0.53 & 0.38 & 0.86 & 0.45 & 0.32 & 0.44 & 0.51 & 0.41 & 0.21 & 0.24 & 0.86 \\
\hline
\end{tabular}

The average concentration of cadmium in all the samples analyzed was $0.12 \mathrm{mg} / \mathrm{kg}$ wet weight. Moreover, all the liver samples were found to contain cadmium concentrations within the maximum level permitted by the Serbian legislation.

Table 2. Occurrence of cadmium in the liver of hogs from 10 pig farms in Vojvodina ( $\mathrm{mg} / \mathrm{kg}$ wet weight)

\begin{tabular}{|c|c|c|c|c|c|c|c|c|c|c|c|}
\hline Farm & I & II & III & IV & V & VI & VII & VIII & IX & $\mathbf{X}$ & Total \\
\hline No & 4 & 2 & 4 & 4 & 2 & 4 & 4 & 2 & 2 & 2 & 30 \\
\hline Average & 0.10 & 0.07 & 0.10 & 0.08 & 0.10 & 0.11 & 0.08 & 0.08 & 0.47 & 0.08 & 0.12 \\
\hline Maximum & 0.13 & 0.07 & 0.12 & 0.10 & 0.11 & 0.16 & 0.09 & 0.08 & 0.48 & 0.09 & 0.48 \\
\hline
\end{tabular}

The Farm IX samples contained higher cadmium concentrations, although only two samples were taken from this farm. The cadmium levels determined were very similar to those reported by a number of other researchers in Serbia (Nikolic et al., 2017; Tomović et al., 2011) or slightly higher (Nikolic et al., 2017). The levels of 
cadmium were higher in the liver of the Mangulica, i.e. free-roaming and extensively reared pigs. Moreover, the cadmium levels in the kidneys also exceeded that permitted by the Serbian legislation (Nikolic et al., 2017). On balance, the levels of cadmium were found to be higher in wild animals most probably because of their prolonged life and the possibility of free-roaming over wider areas (Beukovic \& Popovic, 2019; Bilandžić et al., $2010 \mathrm{~b}$ ). Our study confirmed the presence of cadmium in the region of Vojvodina, most likely as a result of human interference. There is a strong connection between the elevated level of cadmium in animal feed and the increased level of cadmium in the kidneys and livers of pigs (Sapunar-Postružnik et al., 2001). Animal feed is probably the major source of cadmium in the kidneys of the pigs enrolled in our study. Furthermore, the results obtained suggest significant variations in the liver cadmium levels from different pig farms considered. However, some researchers suggest that high individual variations in the kidney levels of cadmium are to be expected even on the same farm and among the same breed and age of pigs (Lindén et al., 2003).

The levels of lead in the liver samples determined in our study were higher than that permitted by the Serbian legislation. In a study conducted in Croatia, the level of lead in the samples of pig kidneys were up to 0.34 $\mathrm{mg} / \mathrm{kg}$, whereas the pig offals contained lead concentrations permitted by the official standards (Bilandžić et al., 2010a). However, the levels of lead in the liver of intensively and extensively reared pigs in Serbia (namely Central Serbia) were much lower (Nikolic et al., 2017). The concentration of lead was also lower in the cattle liver samples than in our study (Tomović et al., 2017). It is a well-known fact that lead is associated with anthropogenic factors, mostly traffic. In general, lead concentrations have been decreasing in recent years due to the phasing out of leaded petrol (Bilandžić et al., 2010a). The phasing out of leaded petrol in Serbia started in 2010. Therefore, the results obtained in this study regarding the lead content in the hog liver are rather surprising. One of the possible explanations is that the premix used in the compound feed could be the source of the lead detected.

\section{CONCLUSION}

The present study examined the occurrence of two heavy metals (namely cadmium $(\mathrm{Cd})$ and lead $(\mathrm{Pb})$ ) in the liver of hogs bred on ten commercial pig farms in the region of Vojvodina. The results obtained indicate that the levels of lead detected in the liver samples from few farms considered exceed the lead level permitted by the Serbian legislation, whereas all the samples analysed were found to contain the permitted cadmium levels. There is a great need for further research on the occurrence and origin of heavy metals in pig edible offals so as to control and minimize their levels and repercussions.

Acknowledgement: This paper was financially supported by the Ministry of Science and Technological Development of the Republic of Serbia, the project entitled "Implementation of Various Rearing - Selection and Biotechnological Methods in Breeding of Pigs" (Project No 31081), and by the Provincial Secretariat for Higher Education and Scientific Research of the AP Vojvodina (Project number:142-451-2689/2018-01/02).

\section{REFERENCES}

Andrée S., Jira W., Schwind K.H., Wagner H., Schwägele F. (2010): Chemical Safety of Meat and Meat Products. Meat Science, 86(1): 38-48.

Beuković D., Jajić I., Krstović S., Beuković M., Lavadinović V.M., Đan M., Veličković, N. (2015): Validation of an Electrothermal Atomic Absorption Spectrometry (ET-AAS) Method for determining $\mathrm{Pb}$ and $\mathrm{Cd}$ in Brown Hare (Lepus europaeus P.) Tissue Samples. Wildlife Biology in Practice, 11(2): 63-69.

Beukovic D. \& Popovic Z. (2019): Exposure of Brown Hare (Lepus europaeus P.) Population to Harmful Effect of Lead (Pb) and Cadmium (C) in the Food Chain. International Symposium on Animal Science (ISAS) 2018, Belgrade, Serbia, 64-68.

Bilandžić N., Dokić M., Sedak M. (2010a): Survey of Arsenic, Cadmium, Copper, Mercury and Lead in Kidney of Cattle, Horse, Sheep and Pigs from Rural Areas in Croatia. Food Additives and Contaminants: Part B Surveillance 3(3): 172-177.

Bilandžić N., Sedak M., Crossed M., Signokić D., Šimić B. (2010b): Wild Boar Tissue Levels of Cadmium, Lead and Mercury in Seven Regions of Continental Croatia. Bulletin of Environmental Contamination and Toxicology, 84(6): 738-743.

EFSA - European Food Safety Authority (2009): Cadmium in Food - Scientific Opinion of the Panel on Contaminants in the Food Chain. EFSA Journal, 980: 1-139.

EFSA - European Food Safety Authority (2010): Scientific Opinion on Lead in Food - Scientific Opinion of the Panel on Contaminants in the Food Chain. EFSA Journal, 8(4): 1570.

European Commission (2008): Commission Regulation (EC) No $^{\circ} 629 / 2008$ of 2 July 2008 amending Regulation (EC) $N^{\circ}$ $1881 / 2006$ as regards maximum levels for certain contaminants in foodstuffs, Off. J. Eur. Union, L173 (2008), pp. 
6-9.

Hutton M. (1983): Sources of Cadmium in the Environment. Ecotoxicology and Environmental Safety, 7(1): 9-24.

IARC - International Agency for Research on Cancer (1993): Some Naturally Occurring Substances: Food Items and Constituents, Heterocyclic Aromatic Amines and Mycotoxins. IARC Monographs on the Evaluation of Carcinogenic Risk of Chemicals to Humans. No. 56. https://doi.org/10.1002/food.19940380335.

Lindén A., Olsson I.M., Bensryd I., Lundh T., Skerfving S., Oskarsson A. (2003): Monitoring of Cadmium in the Chain from Soil via Crops and Feed to Pig Blood and Kidney. Ecotoxicology and Environmental Safety, 55(2): 213-222.

Nikolic D., Djinovic-Stojanovic J., Jankovic S., Stanisic N., Radovic C., Pezo L., Lausevic M. (2017): Mineral Composition and Toxic Element Levels of Muscle, Liver and Kidney of Intensive (Swedish Landrace) and Extensive (Mangulica) Pigs from Serbia. Food Additives and Contaminants - Part A Chemistry, Analysis, Control, Exposure and Risk Assessment, 34(6): 962-971.

Nikolic D., Jankovic S., Djinovic-Stojanovic J., Radicevic T., Stefanovic S., Spiric D., Simunovic S. (2019): Cadmium Level Trend in Liver and Kidney of Pigs from Serbia during 2014-2018. IOP Conference Series: Earth and Environmental Science, The $60^{\text {th }}$ International Meat Industry Conference MEATCON2019 22-25 September 2019, Kopaonik-Serbia, 333: 012088.

Reddy K.E., Park K.R., Lee S.D., Yoo J.H., Son A.R., Lee H. L. (2017): Effects of Graded Concentrations of Supplemental Lead on Lead Concentrations in Tissues of Pigs and Prediction Equations for Estimating Dietary Lead Intake. PeerJ, 5:e3936.

RS Pravilnik (2011): Pravilnik o količinama pesticida, metala i metaloida i drugih otrovnih supstancija, hemioterapeutika, anabolika i drugih supstancija koje se mogu nalaziti u namirnicama. "Službeni list SRJ", br. 5/92, 11/92-ispr. i 32/2002 i "Sl. glasnik RS," br. 25/2010-dr. pravilnik i 28/2011-pravilnik.

Sapunar-Postružnik J., Bažulić D., Grubelić M., Kubala Drinčić H., Njari B. (2001): Cadmium in Animal Feed and in Foodstuffs of Animal Origin. Food Technology and Biotechnology, 39(1): 67-71.

Spahić Poznanović M., Sakan S., Cvetković Ž., Tančić P., Trifković J., Nikić Z., Manojlović D. (2018): Assessment of Contamination, Environmental Risk, and Origin of Heavy Metals in Soils Surrounding Industrial Facilities in Vojvodina, Serbia. Environmental Monitoring and Assessment, 190: 208.

Statistical Office of the Republic of Serbia (2018): Statistical Yearbook of the Republic of Serbia 2018. Beograd.

Tomović, V.M., Petrović L.J.S., Tomović M.S., Kevrešanc Z.S., Jokanović M.R., Džinić N.R., Despotović A.R. (2011): Cadmium Concentrations in the Liver of 10 Different Pig Genetic Lines from Vojvodina, Serbia. Food Additives and Contaminants: Part B Surveillance 4(3): 180-184.

Tomović V., Jokanović M., Tomović M., Lazović M., Šojić B., Škaljac S., Ivić M., Koćić-Tanackov S., Tomašević I., Martinović A. (2017): Cadmium and Lead in Female Cattle Livers and Kidneys from Vojvodina, Northern Serbia. Food Additives and Contaminants: Part B Surveillance 10(1): 39-43.

Submitted: 29.10.2020.

Accepted: 16.11.2020. 